\title{
Lactation performance and rumen fermentation in dairy cows fed a diet with alfalfa hay replaced by corn stover and supplemented with molasses
}

\author{
Zi-Hai Wei', Shu-Lin Liang ${ }^{1}$, Di-Ming Wang ${ }^{1}$, Hong-Yun Liu ${ }^{1}$, Metha Wanapat ${ }^{2}$, and Jian-Xin Liu ${ }^{1, *}$
}

\begin{abstract}
* Corresponding Author: Jian-Xin Liu Tel: +86-571-88982097, Fax: +86-571-88982097, E-mail: liujx@zju.edu.cn
\end{abstract}

'Institute of Dairy Science, College of animal Science, Zhejiang University, Hangzhou, Zhejiang 310058, China

${ }^{2}$ Tropical Feed Resources Research and Development Center (TROFREC), Department of Animal Science, Faculty of Agriculture, Khon Kaen University, Khon Kaen 40002, Thailand

ORCID

Zi-Hai Wei

https://orcid.org/0000-0001-9416-8821

Shu-Lin Liang

https://orcid.org/0000-0002-4690-0149 Di-Ming Wang

https://orcid.org/0000-0002-1451-6863

Hong-Yun Liu

https://orcid.org/0000-0001-8806-6204

Metha Wanapat

https://orcid.org/0000-0002-7633-052X

Jian-Xin Liu

https://orcid.org/0000-0002-5812-5186

Submitted Sept 30, 2018; Revised Oct 13, 2018; Accepted Jan 8, 2019
Objective: The objective of current study was to investigate the lactation performance and rumen fermentation characteristics of dairy cows fed a diet with alfalfa hay replaced by corn stover but supplemented with molasses.

Methods: Sixteen Holstein cows in mid-lactation were randomly assigned to 1 of 2 dietary treatments: i) alfalfa based diet (AH), and ii) corn stover based diet supplemented with molasses (CSM). The experiment was conducted according to a $2 \times 2$ crossover design with 22-d each period, consisting of $17 \mathrm{~d}$ for adaptation and $5 \mathrm{~d}$ for data and samples collection. Results: Dry matter intake and milk yield were higher for cows fed AH than CSM ( $p<0.01)$. Milk protein content and nitrogen conversion were higher $(\mathrm{p}<0.05)$, while milk urea nitrogen was lower $(\mathrm{p}<0.01)$ for cows fed AH than CSM-fed cows. Contents of milk total solids, fat and lactose were not different between two groups $(\mathrm{p}>0.10)$. Total rumen volatile fatty acid concentration tended to be higher $(\mathrm{p}=0.06)$ for cows fed AH than CSM-fed cows. Molar proportion of acetate was lower $(p=0.04)$, but valerate was higher $(p=0.02)$ in cows fed AH than CSM-fed cows. Rumen concentration of propionate, and isobutyrate, and ratio of acetate to propionate tended to be different $(\mathrm{p}<0.10)$ between two groups. The feed cost per kilogram of milk was lower in CSM than $\mathrm{AH}(\mathrm{p}<0.01)$. No differences were found in feed efficiency and most plasma parameters tested ( $\mathrm{p}>0.10)$.

Conclusion: In comparison with $\mathrm{AH}$ diet, CSM diet could be fed to dairy cows without negative effect on feed efficiency, ruminal fermentation, but economically beneficial, indicating that CSM could be an alternative choice for dairy farms instead of AH to feed midlactation dairy cows.

Keywords: Alfalfa Hay; Corn Stover; Dairy Cows; Lactation Performance; Molasses

\section{INTRODUCTION}

With the development of global dairy industry, the price of alfalfa has increased to a relatively high level, and demand for alfalfa is likely to keep on-growing in future [1]. However, alfalfa yield in its main producing regions such as United States of America tends to decline [2]. Countries such as China where alfalfa production cannot meet the dairy industry demand have to import large amount of alfalfa with high price [1-3].

Along with the corn grain production, huge amounts of corn stover (CS) are produced, representing a meaningful forage resource that can be used for ruminant livestock production. Abundant source of CS is also available for livestock in China, with over 200 million tons of CS produced annually [4,5], but these resources are not reasonably utilized and even cause severe pollution to the environment due to open burning [6,7]. Thus, it is a strategic policy for the developing countries to make full use of crop coproducts such as CS, to meet 
the requirement of forage and reduce the dependence on imported alfalfa hay $(\mathrm{AH})$.

Non-fiber carbohydrates (NFC) including starch, sugars and pectin, are the main energy source of the diets for dairy cows [8]. Compared with alfalfa-containing diet, the diets with different forage sources but with an equivalent content of NFC and forage neutral detergent fiber (NDF) have no unfavorable effect on the ruminal fermentation and productive performance of dairy cows [9]. However, higher NFC content in alfalfa-based diet may contribute to higher feed efficiency and milk protein yield of dairy cows than in CS based diet $[10,11]$. In the previous study [12], we found that increasing the NFC content of CS-containing diet improved feed efficiency that reached a value similar to alfalfa-containing diet, but the feed intake was decreased, and subsequent milk yield was lower than that of $\mathrm{AH}$-fed cows. Molasses is rich in sugar which could be a source of dietary NFC, and can improve diet palatability and lactation performance of dairy cows [13]. Therefore, it is hypothesized that supplementation of the CS contained diet with molasses to balance NFC content could improve lactation performance and nutrient utilization of dairy cow to a level that approaches to those fed alfalfa based diet.

\section{MATERIALS AND METHODS}

\section{Animals, feeds, and design}

The experiment was conducted at the Hangjiang Dairy Farm (Hangzhou, China). The Zhejiang University Institutional Animal Care and Use Committee approved all procedures involving animals (Approval No. ZJU20160375). Sixteen Holstein cows in mid-lactation (days in milk $=161 \pm 10.3$ ) were randomly assigned to 1 of 2 dietary treatments: i) AH diet, ii) CS based diet supplemented with molasses (CSM). The experiment was conducted according to a $2 \times 2$ crossover design with $22-\mathrm{d}$ each period, including $17 \mathrm{~d}$ for adaptation and $5 \mathrm{~d}$ for data and samples collection. The experimental diets were formulated according to Cornell-Penn-Miner dairy 3.0 dairy nutrition model [14] to meet the nutritional requirements of the cows. Both diets were isonitrogenous and isocaloric, and had similar NFC content (Table 1). The CS used was purchased from Yutian County, Hebei Province, which is one of the main corn grain-producing regions in China. The CS was naturally dried after corn grain collection, cut to about $5 \mathrm{~cm}$ long with a straw cutter, and then baled for selling. The determined chemical composition of CS and AH are listed in the footnote part of Table 1. Diets price was estimated based on the purchased price of the ingredients on farm. The feed cost per kilogram of milk was calculated by dividing the feed costs by milk yield.

All cows housed in a tie-stall barn were fed experimental total mixed ration (TMR) and had free access to drink water. The diets were offered ad libitum to allow at least $10 \%$ orts,
Table 1. Ingredients of the experimental diets

\begin{tabular}{|c|c|c|}
\hline \multirow{2}{*}{ Items } & \multicolumn{2}{|c|}{ Treatment $^{1)}$} \\
\hline & $\mathrm{AH}$ & CSM \\
\hline DM (\%) & 48.57 & 47.75 \\
\hline \multicolumn{3}{|c|}{ Dietary ingredient ( $\mathrm{g} / \mathrm{kg}$ of DM) } \\
\hline Alfalfa hay & 147 & 0 \\
\hline Oat hay & 66.6 & 53.7 \\
\hline Corn stover & 0 & 146 \\
\hline Corn silage & 252 & 260 \\
\hline Ground corn grain & 168 & 147 \\
\hline Soybean meal & 130 & 184 \\
\hline Wheat bran & 152 & 51.2 \\
\hline Beet pulp & 71.0 & 92.7 \\
\hline Molasses & 0 & 51.2 \\
\hline Premix ${ }^{2)}$ & 13.2 & 13.2 \\
\hline \multicolumn{3}{|c|}{ Chemical composition ( $\mathrm{g} / \mathrm{kg}$ of DM) } \\
\hline $\mathrm{CP}$ & 157 & 160 \\
\hline NDF & 360 & 371 \\
\hline ADF & 199 & 207 \\
\hline Crude ash & 65 & 71 \\
\hline Ether extracts & 38 & 34 \\
\hline $\mathrm{NFC}^{3)}$ & 379 & 364 \\
\hline $\mathrm{NE}_{\mathrm{L}}^{4)}(\mathrm{MJ} / \mathrm{kg})$ & 7.11 & 7.03 \\
\hline Diet price (USD/kg DM) & 0.343 & 0.319 \\
\hline
\end{tabular}

DM, dry matter; $C P$, crude protein; NDF, neutral detergent fiber; ADF, acid detergent fiber; NFC, non-fiber carbohydrate; $\mathrm{NE}_{\mathrm{L}}$, net energy for lactation.

${ }^{1)} \mathrm{AH}$, alfalfa hay based diet; CSM, corn stover based diet supplemented with molasses. Chemical compositions of the corn stover and alfalfa hay are as follows: corn stover (\% of DM): $6.64 \%$ CP, $68.13 \%$ NDF, $41.45 \%$ ADF, and $9.54 \%$ ash; alfalfa hay (\% of DM): $14.90 \%$ CP, $43.50 \%$ NDF, 32.76\% ADF, and $8.71 \%$ ash.

${ }^{2)}$ Contained (per kilogram of DM): 540 KIU of vitamin A, 112 KIU of vitamin D, 4,500 IU of vitamin $E_{1} 1,510 \mathrm{mg}$ of $\mathrm{Fe}, 1,520 \mathrm{mg}$ of $\mathrm{Cu}, 7,880 \mathrm{mg}$ of $\mathrm{Zn}, 1,530$ $\mathrm{mg}$ of $\mathrm{Mn}, 50 \mathrm{mg}$ of Se, $100 \mathrm{mg}$ of I, $20 \mathrm{mg}$ of $\mathrm{Co}$, water $\leq 10 \%$.

${ }^{3)} \mathrm{NFC}=100-\%$ NDF- $\%$ CP-\% ether extracts- $\%$ ash (NRC [8]).

4) $\mathrm{NE}_{\mathrm{L}}$ were estimated according to CPM dairy 3.0.

and cows were fed 3 times daily at 0730,1400 , and 1930 and milked 3 times daily at 0800,1430 , and 2000, respectively.

\section{Sampling, measurements, and analyses}

The feed offered and orts were recorded daily during $\mathrm{d} 18$ to 22. The samples of TMR and orts were taken three times at each feeding time on $\mathrm{d} 20$. All the samples were stored in sealed plastic bags at $-20^{\circ} \mathrm{C}$. The samples were dried at $65^{\circ} \mathrm{C}$ for $48 \mathrm{~h}$, ground through a Wiley mill with $2 \mathrm{~mm}$-mesh screen (Thomas-Wiley Laboratory Mill, Ramsey, MN, USA) followed by $1 \mathrm{~mm}$-mesh screen (Tecator 1093, Hoganas, Sweden), and then used for chemical analysis of dry matter $\left(\mathrm{DM}, 105^{\circ} \mathrm{C}\right.$ for $5 \mathrm{~h}$ ), crude protein (CP,\#988.05), ether extract (\#920.39), crude ash (\#942.05), and acid detergent fiber (ADF, \#973.18) according to AOAC methods [15]. The content of NDF was analyzed according to the method of Van Soest et al [16] with $a$-amylase and sodium sulfite added. An ANKOM2000 fiber analyzer (Ankom Technology Corp., Macedon, NY, USA) was used to extract and filter NDF and ADF. Ingredient and 
chemical composition of the diets are presented in Table 1.

Milk yield and milk samples were recorded and collected daily during $\mathrm{d} 18$ to 22 . The samples for each day were composited proportionally (4:3:3 according to three times of milking), stored with addition of bronopol tablets (milk preservative; D \& F Control System Inc., San Ramon, CA, USA), and sent to the Shanghai DHI Testing Center to analyze milk protein, fat, lactose, total solids, milk urea nitrogen (MUN) and somatic cell count (SCC) using Combi Foss FT+ instrument (Foss Electric, Hillerød, Denmark). The body weight (BW) of each cow was measured at the beginning and end of each period with a weighing scale.

On d 21 of each period, blood samples were obtained approximately $3 \mathrm{~h}$ after morning feeding from coccygeal artery and mammary vein, respectively, into heparinized vacuum tubes, and then centrifuged at $3,000 \times g$ for $15 \mathrm{~min}$ to obtain plasma, which was stored at $-20^{\circ} \mathrm{C}$ for later analysis. Plasma samples were analyzed for total protein, albumin, blood urea nitrogen, glucose, nonesterified fatty acid (NEFA), and cholesterol by using Auto Analyzer 7020 instrument (Hitachi High-technologies Corporation, Tokyo, Japan) with colorimetric commercial kits (Ningbo Medical System Biotechnology Co., Ltd, Zhejiang, China).

Rumen fluid samples (approximately $100 \mathrm{~mL}$ ) were collected using an oral stomach tube [17] after collection of blood samples. The rumen fluid $\mathrm{pH}$ was measured immediately using a pH meter (FE20-FiveEasy Plus; Mettler Toledo Instruments Co. Ltd., Shanghai, China). Triplicate 1-mL samples were acidified with $20 \mu \mathrm{L}$ of orthophosphoric acid, and triplicate $1-\mathrm{mL}$ original samples were frozen at $-20^{\circ} \mathrm{C}$ for later analysis of volatile fatty acid (VFA) and ammonia nitrogen $\left(\mathrm{NH}_{3}-\mathrm{N}\right)$, with the methods as described by $\mathrm{Hu}$ et al [18].

\section{Statistical analysis}

Data on DM intake, lactation performance, feed cost per kilogram of milk, and feed efficiency were averaged per period and analyzed using the PROC MIXED procedure of the SAS software (SAS, 2000); and the BW gain, rumen fluids variables, and blood samples parameters were also analyzed using the PROC MIXED procedure. The model included period, treatment, and treatment sequence of the animal as the fixed effects, and cow within the sequence as a random effect. The results were listed as least squares means, and were separated using the pdiff option when the fixed effects were significant. Significant difference was declared as $\mathrm{p}<0.05$ and $0.05 \leq \mathrm{p} \leq 0.10$ was defined as statistical trends.

\section{RESULTS}

\section{Lactation performance}

Feed intake and lactation performance are presented in Table 2. The dry matter intake, milk yield and energy-corrected milk
Table 2. Lactation performance in dairy cows fed experimental diets

\begin{tabular}{|c|c|c|c|c|}
\hline \multirow{2}{*}{ Items } & \multicolumn{2}{|c|}{ Treatment $^{1)}$} & \multirow{2}{*}{ SEM } & \multirow{2}{*}{$p$-value } \\
\hline & $\mathrm{AH}$ & CSM & & \\
\hline DMI (kg/d) & $23.84^{a}$ & $22.55^{b}$ & 0.32 & $<0.01$ \\
\hline Milk yield (kg/d) & $26.61^{\mathrm{a}}$ & $25.22^{b}$ & 1.00 & $<0.01$ \\
\hline $\mathrm{ECM}^{2)}(\mathrm{kg} / \mathrm{d})$ & $30.20^{a}$ & $28.58^{b}$ & 0.79 & $<0.01$ \\
\hline \multicolumn{5}{|l|}{ Milk composition (g/kg) } \\
\hline Total solid & 131.8 & 131.3 & 2.00 & 0.35 \\
\hline Fat & 41.05 & 40.88 & 1.41 & 0.74 \\
\hline Protein & $36.18^{\mathrm{a}}$ & $35.77^{b}$ & 0.84 & 0.04 \\
\hline Lactose & 49.79 & 49.55 & 0.44 & 0.13 \\
\hline MUN (mg/dL) & $17.88^{b}$ & $19.16^{\mathrm{a}}$ & 0.62 & $<0.01$ \\
\hline $\operatorname{SCC}\left(\times 10^{3}\right) / \mathrm{mL}$ & 83.46 & 69.81 & 19.4 & 0.25 \\
\hline Nitrogen conversion ${ }^{3)}$ & $0.254^{\mathrm{a}}$ & $0.246^{b}$ & 0.005 & 0.02 \\
\hline Feed efficiency ${ }^{3)}$ & 1.27 & 1.27 & 0.03 & 0.88 \\
\hline Feed cost per kg milk (USD/kg) & $0.313^{\mathrm{a}}$ & $0.286^{b}$ & 0.011 & $<0.01$ \\
\hline BW gain $(g / d)$ & 493 & 343 & 130 & 0.43 \\
\hline
\end{tabular}

SEM, standard error of the mean; DMI, dry matter intake; ECM, energy-corrected milk; MUN, milk urea nitrogen; SCC, somatic cell count; BW, body weight.

${ }^{1)} \mathrm{AH}$, alfalfa hay based diet; CSM, corn stover based diet supplemented with molasses.

2) $\mathrm{ECM}(\mathrm{kg})=0.3246 \times$ milk yield $(\mathrm{kg})+13.86 \times$ fat yield $(\mathrm{kg})+7.04 \times$ protein yield (kg) [27].

3) Nitrogen conversion = milk protein yield/CP intake; Feed efficiency expressed as ECM $(\mathrm{kg}) / \mathrm{DMl}(\mathrm{kg})$.

${ }^{a-c}$ Least squares means within a row with different superscripts differ $(p<0.05)$.

(ECM) were higher in cows fed AH than in CSM-fed cows $(\mathrm{p}<0.01)$. Milk protein content and nitrogen conversion (milk protein yield/CP intake) was higher $(\mathrm{p}<0.05)$ and MUN was lower $(\mathrm{p}<0.01)$ for cows fed AH compared with CSM-fed cows. No differences were found in feed efficiency (ECM/DM intake), contents of milk total solids, milk fat and lactose, SCC and BW gain between two groups ( $p>0.10$ ). The feed cost per kilogram of milk was lower for cows fed CSM than for AH-fed cows $(\mathrm{p}<0.01)$.

\section{Rumen fermentation parameters}

The results of rumen fermentation variables are presented in Table 3. Rumen $\mathrm{pH}$ tended to be lower $(\mathrm{p}=0.06)$, while total VFA concentration tended to be higher $(p=0.06)$ for cows fed $\mathrm{AH}$ than CSM-fed cows. Molar proportion of acetate was lower $(\mathrm{p}=0.04)$, but valerate was higher $(\mathrm{p}=0.02)$ in $\mathrm{AH}$ than in CSM ( $p=0.02)$. We found a tendency of difference in rumen concentration of propionate $(p=0.09)$, isobutyrate $(p=$ $0.09)$, and ratio of acetate to propionate $(\mathrm{p}=0.07)$ between two groups, with no differences in NH3-N, butyrate and isovalerate $(\mathrm{p}>0.10)$.

\section{Blood variables}

No significant differences were found in the concentration of plasma total protein, albumin, glucose, NEFA and cholesterol between cows of the two groups ( $p>0.05)$, but the cows fed CSM had higher urea nitrogen in coccygeal artery $(p=0.04)$ 
Table 3. Ruminal fermentation variables in dairy cows fed experimental diets

\begin{tabular}{|c|c|c|c|c|}
\hline \multirow{2}{*}{ Items } & \multicolumn{2}{|c|}{ Treatment $^{1)}$} & \multirow{2}{*}{ SEM } & \multirow{2}{*}{ p-value } \\
\hline & $\mathrm{AH}$ & CSM & & \\
\hline pH & 6.16 & 6.31 & 0.07 & 0.06 \\
\hline Ammonia nitrogen (mg/dL) & 17.4 & 18.1 & 1.02 & 0.54 \\
\hline Total VFA (mM) & 107 & 103 & 2.18 & 0.06 \\
\hline \multicolumn{5}{|c|}{ Molar proportion (mmoL/100 mmoL) } \\
\hline Acetate & $68.80^{b}$ & $69.86^{\mathrm{a}}$ & 0.44 & 0.04 \\
\hline Propionate & 16.54 & 15.44 & 0.46 & 0.09 \\
\hline Isobutyrate & 0.62 & 0.66 & 0.02 & 0.09 \\
\hline Butyrate & 11.38 & 11.44 & 0.30 & 0.86 \\
\hline Isovalerate & 1.37 & 1.41 & 0.10 & 0.72 \\
\hline Valerate & $1.28^{\mathrm{a}}$ & $1.18^{\mathrm{b}}$ & 0.03 & 0.02 \\
\hline Acetate:propionate & 4.23 & 4.57 & 0.13 & 0.07 \\
\hline
\end{tabular}

SEM, standard error of the mean; VFA, volatile fatty acid.

${ }^{1)} \mathrm{AH}$, alfalfa hay based diet; CSM, corn stover based diet supplemented with molasses.

${ }^{a-b}$ Least squares means within a row with different superscripts differ $(p<0.05)$.

and mammary vein $(\mathrm{p}=0.02)$ than the AH-fed cows had (Table 4).

\section{DISCUSSION}

Chemical composition, physical and digestion characteristics of alfalfa may cause a shorter ruminal retention time of feed particles than other forage particles [19], which may account for the higher DM intake in AH group than in CSM. Increasing energy intake can improve milk yield [20,21], thus higher DM intake in AH group supplied more energy and nutrients for milk synthesis and resulted higher milk yield in AH group than CSM. Higher supply of metabolizable protein (MP) could be expected from higher dietary content of NFC [10]. The MP supply, though not determined, might be higher in AH than in CSM in the current study, resulting in a higher milk protein content in $\mathrm{AH}$ (Table 2) since milk protein secretion in

Table 4. Plasma metabolites of dairy cows fed experimental diets

\begin{tabular}{|c|c|c|c|c|}
\hline \multirow{2}{*}{ Items } & \multicolumn{2}{|c|}{ Treatment $^{1)}$} & \multirow{2}{*}{ SEM } & \multirow{2}{*}{$\mathrm{p}$-value } \\
\hline & $\mathrm{AH}$ & CSM & & \\
\hline Total protein (g/L) & 77.65 & 76.78 & 1.36 & 0.13 \\
\hline Albumin (g/L) & 26.89 & 26.85 & 0.44 & 0.89 \\
\hline \multicolumn{5}{|l|}{ Urea nitrogen (mmol/L) } \\
\hline In coccygeal artery & $6.38^{b}$ & $6.76^{\mathrm{a}}$ & 0.28 & 0.04 \\
\hline In mammary vein & $6.29^{b}$ & $6.82^{\mathrm{a}}$ & 0.27 & 0.02 \\
\hline \multicolumn{5}{|l|}{ Glucose (mmol/L) } \\
\hline In coccygeal artery & 3.51 & 3.38 & 0.08 & 0.12 \\
\hline In mammary vein & 2.53 & 2.42 & 0.09 & 0.26 \\
\hline NEFA (umol/L) & 85.98 & 87.35 & 5.27 & 0.86 \\
\hline Cholesterol (mmol/L) & 5.23 & 5.09 & 0.29 & 0.28 \\
\hline
\end{tabular}

SEM, standard error of the mean; NEFA, nonesterified fatty acid.

1) AH, alfalfa hay based diet; CSM, corn stover based diet supplemented with

molasses. The results were from mammary vein samples other than special note. dairy cows is closely associated with the supply of MP [8]. The lower price of diet CSM compared with AH (Table 1) resulted in reduced feed cost per kilogram of milk in CSM, indicating higher income of each kilogram milk in CSM, which are economically beneficial for dairy farms.

Higher concentration of total VFA in AH group may be attributed to the lower NDF and higher NFC compared to the CSM. This might result in lower $\mathrm{pH}$ for $\mathrm{AH}$ group than for CSM (Table 3). Rumen $\mathrm{NH}_{3}-\mathrm{N}$ was not different between two groups in current study (Table 3), inconsistent with the previous finding that the cows fed CS-based diet had a higher rumen $\mathrm{NH}_{3}-\mathrm{N}$ than cows fed AH-based diet with no difference in $\mathrm{pH}$ value $[11,22]$. Higher $\mathrm{pH}$ may cause a higher rate of $\mathrm{NH}_{3}-\mathrm{N}$ absorption because less $\mathrm{NH}_{3}-\mathrm{N}$ is converted to ammonium that is absorbed more slowly than $\mathrm{NH}_{3}-\mathrm{N}$ [23], finally resulting in no difference of $\mathrm{NH}_{3}-\mathrm{N}$ between two groups (Table 3). Ammonia absorbed through the rumen wall is converted to urea in the liver and excreted in the urine and milk [24], which is reflective of higher MUN in CSM compared to AH. Higher NFC diets [25] or alfalfa based diet [26] had higher molar propionate proportion and lower acetate proportion. Though we designed to have a similar NFC content in $\mathrm{AH}$ and CSM in current study, the actual NFC content was a little higher in AH than CSM (Table 1), which may also contribute to the higher molar propionate proportion and lower acetate proportion in AH than CSM, and result in lower acetate: propionate in $\mathrm{AH}$ than in CSM (Table 3).

No differences in BW change and plasma parameters between two diets indicate no adverse effects of feeding diet CSM to lactating cows compared with AH. In combination with lower feed cost per kilogram of milk, diet CSM could be used for dairy cows to replace $\mathrm{AH}$.

\section{IMPLICATIONS}

In comparison with $\mathrm{AH}$, diet $\mathrm{CSM}$ could be fed to dairy cows without negative effect on feed efficiency, ruminal fermentation, and blood biochemical variables, but is beneficial for dairy farms with economic merit. Our results indicate that supplementing CS diet with molasses could be an alternative choice for dairy farms instead of $\mathrm{AH}$ to feed mid-lactation dairy cows.

\section{CONFLICT OF INTEREST}

We certify that there is no conflict of interest with any financial organization regarding the material discussed in the manuscript.

\section{ACKNOWLEDGMENTS}

This study was financially supported by the China Agriculture 
Research System (No. CARS-36) and National Nature Science Foundation of China (No. 31872380). We gratefully thank the staff of the Hangjiang Dairy Farm (Hangzhou, China) for their assistance in caring for the animals.

\section{REFERENCES}

1. Sumner DA, Rosen-Molina JT. Alfalfa in the context of global crop price prospects. Western Alfalfa and Forage Conference; 2011 December 11-13; Las Vegas, NV, USA. p. 11-3.

2. USDA National Agricultural Statistics Service (USDA-NASS). Historical Track Records - Crop Production; 2018 April 12. Available from: https://downloads.usda.library.cornell.edu/ usda-esmis/files/c534fn92g/6q182n624/v405sd06x/htrcp-0412-2018.pdf

3. Wang Q, Hansen J, Xu F. China's emerging dairy markets and potential impacts on US alfalfa and dairy product exports. Annual Meeting; 2016 Jul 31-Aug 2; Boston, MA, USA. Agricultural and Applied Economics Association; 2016 (235833).

4. Lv K, Qiu H, Bai J, Xu Z. Development of direct return of corn stalk to soil: current status, driving forces and constraints. China Popul Resour Environ 2013;23:171-6.

5. Zuo X, Wang HY, Wang YJ, Wang L, Jing L, Wang DL. Estimation and suitability evaluation of corn straw resources in China. Chinese J Agric Resour Reg Plann 2015;6:5-10.

6. Li J, Bo Y, Xie S. Estimating emissions from crop residue open burning in China based on statistics and MODIS fire products. J Environ Sci 2016;44:158-70. https://doi.org/10.1016/j.jes.2015. 08.024

7. Zhang L, Liu Y, Hao L. Contributions of open crop straw burning emissions to PM2.5 concentrations in China. Environ Res Lett 2016;11:014014. https://doi.org/10.1088/1748-9326/11/ $1 / 014014$

8. National Research Council (NRC). Nutrient requirements of dairy cattle. 7th rev ed. Washington, DC, USA: National Academy Press; 2001.

9. Xu J, Hou YJ, Yang HB, et al. Effects of forage sources on rumen fermentation characteristics, performance, and microbial protein synthesis in midlactation cows. Asian-Australas J Anim Sci 2014;27:667-73. https://doi.org/10.5713/ajas.2013. 13604

10. Zhu W, Fu Y, Wang B, et al. Effects of dietary forage sources on rumen microbial protein synthesis and milk performance in early lactating dairy cows. J Dairy Sci 2013;96:1727-34. https://doi.org/10.3168/jds.2012-5756

11. Wang B, Mao SY, Yang HJ, et al. Effects of alfalfa and cereal straw as a forage source on nutrient digestibility and lactation performance in lactating dairy cows. J Dairy Sci 2014;97:770615. https://doi.org/10.3168/jds.2014-7961

12. Wei ZH, Zhang BX, Liu JX. Effects of the dietary nonfiber carbohydrate content on lactation performance, rumen fermentation, and nitrogen utilization in mid-lactation dairy cows receiving corn stover. J Anim Sci Biotechnol 2018;9:20. https:// doi.org/10.1186/s40104-018-0239-Z

13. Broderick GA, Radloff WJ. Effect of molasses supplementation on the production of lactating dairy cows fed diets based on alfalfa and corn silage. J Dairy Sci 2004;87:2997-3009. https:// doi.org/10.3168/jds.S0022-0302(04)73431-1

14. Tedeschi LO, Chalupa W, Janczewski E, Fox DG, Sniffen C, Munson R. Evaluation and application of the CPM Dairy Nutrition model. J Agric Sci 2008;146:171-82. https://doi. org/10.1017/S0021859607007587

15. Latimer GW. AOAC International. Official methods of analysis of AOAC International. 19th ed. Gaithersburg, MD, USA: AOAC International; 2012.

16. Van Soest PJ, Robertson JB, Lewis BA. Methods for dietary fiber, neutral detergent fiber, and nonstarch polysaccharides in relation to animal nutrition. J Dairy Sci 1991;74:3583-97. https://doi.org/10.3168/jds.S0022-0302(91)78551-2

17. Shen JS, Chai Z, Song LJ, Liu JX, Wu YM. Insertion depth of oral stomach tubes may affect the fermentation parameters of ruminal fluid collected in dairy cows. J Dairy Sci 2012;95: 5978-84. https://doi.org/10.3168/jds.2012-5499

18. Hu WL, Liu JX, Ye JA, Wu YM, Guo YQ. Effect of tea saponin on rumen fermentation in vitro. Anim Feed Sci Technol 2005; 120:333-9. https://doi.org/10.1016/j.anifeedsci.2005.02.029

19. Voelker Linton JA, Allen MS. Nutrient demand interacts with forage family to affect intake and digestion responses in dairy cows. J Dairy Sci 2008;91:2694-701. https://doi.org/10.3168/ jds.2007-0897

20. Ballard CS, Mandebvu P, Sniffen CJ, Emanuele SM, Carter MP. Effect of feeding an energy supplement to dairy cows preand postpartum on intake, milk yield, and incidence of ketosis. Anim Feed Sci Technol 2001;93:55-69. https://doi.org/10. 1016/S0377-8401(01)00270-X

21. Maltz E, Barbosa LF, Bueno P, et al. Effect of feeding according to energy balance on performance, nutrient excretion, and feeding behavior of early lactation dairy cows. J Dairy Sci 2013; 96:5249-66. https://doi.org/10.3168/jds.2013-6549

22. Zhu W, Tang CH, Sun XP, et al. Effects of starch and rumenprotected amino acid supplementation on rumen microbial protein synthesis and milk performance in lactating cows fed corn stover. J Anim Vet Adv 2013;12:633-39.

23. Abdoun K, Stumpff F, Martens H. Ammonia and urea transport across the rumen epithelium: a review. Anim Health Res Rev 2006;7:43-59. https://doi.org/10.1017/S1466252307001156

24. Linn JG, Olson JD. Using milk urea nitrogen to evaluate diets and reproductive performance of dairy cattle. State Applied Nutrition Management Conference 1995; La Crosse, University of Wisconsin, Madison, WI, USA; 1995;4:155-67.

25. Ma T, Tu Y, Zhang NF, Deng KD, Diao QY. Effect of the ratio of non-fibrous carbohydrates to neutral detergent fiber and protein structure on intake, digestibility, rumen fermentation, and nitrogen metabolism in lambs. Asian-Australas J Anim 
Sci 2015;28:1419-26. https://doi.org/10.5713/ajas.15.0025

26. Hansen WP, Otterby DE, Linn JG, Donker JD. Influence of forage type, ratio of forage to concentrate, and methionine hydroxy analog on performance of dairy cows. J Dairy Sci 1991;74:1361-9. https://doi.org/10.3168/jds.S0022-0302(91)
78291-X

27. Orth R. Sample day and lactation report, DHIA 200. Fact Sheet A-2. Mid-States Dairy Records Processing Center (DRPC), Ames, IA, USA; 1992. 